\title{
DEVELOPING ENGLISH MATERIAL FOR CRUISE LINE BARTENDER FOR STUDENTS OF INTERNATIONAL BALI INSTITUTE OF TOURISM
}

\author{
Ni Made Sri Rahayu1), I Gede Budasi² \\ 1, 2 English Language Education, Post Graduate Program, \\ Universitas Pendidikan Ganesha, Singaraja \\ Email: nimadesrirahayu3030@gmail.com, yaysurya8@yahoo.com
}

\begin{abstract}
ABSTRAK
Penelitian ini bertujuan untuk mengembangkan bahan pembelajaran Bahasa Inggris untuk kapal pesiar yang dibutuhkan oleh mahasiswa jurusan kapal pesiar khusunya bartender di Sekolah Tinggi Pariwisata Bali Internasional, mendeskripsikan bagaimana bahan pembelajaran dikembangkan, dan menganalisa kualitas bahan pembelajaran yang telah dikembangkan. Penelitian ini menggunakan model penelitian danyang dikembangkan terdiri atas beberapa tahap; 1) melaksanakan analisis kebutuhan, 2) mendesain model, 3) mengembangan model, 4) validasi oleh ahli dan 5) diseminasi (mencoba model). Objek penelitian ini adalah bahasa Inggris jurusan kapal pesiar khususnya bartender di Sekolah Tinggi Pariwisata Bali International. Instrumen penelitian yang digunakan dalam penelitian ini, yaitu kuesioner, wawancara, dan analisis dokumen. Hasil temuan dalam penelitian ini menunjukan bahwa ada delapan topik yang perlu dikembangkan yakni getting to know you, setting up a bar, kinds of drink, drink recipe, and taking beverage order, we are sorry, cruise vacationers, and job interview. Bahan pembelajaran yang dikembangkan mengikuti rancangan bahan English for Specific Purposes. Serta mengikuti langkah yang digunakan dalam menganalisis data yang mecakup reduksi data, pemaparan data, dan penarikan kesimpulan. Hasil dari uji ahli dianalisis secara deskriptif dengan membandingkan skor dari dua ahli. Kualitas dari materi yang dikembangkan dapat dikategorikan sebagai materi pembelajaran yang baik. Oleh karena itu, materi yang dikembangkan dapat digunakan sebagai sumber belajar pada jurusan kapal pesiar untuk bartender pada sekolah Tinggi Pariwisata Bali Internasional.
\end{abstract}

Kata kunci: Materi Pembelajaran Bahasa Inggris, ESP, Bahasa Inggris untuk Bartender.

\begin{abstract}
This study aims to develop English for Cruise Line Bartender materials needed by Cruise Line Bartender students of The International Bali Institute of Tourism, to explain how the materials were developed, and to analyze the quality of the developed materials. The model consists of several stages; 1) conducting need analysis (problem determination), 2) designing the model, 3) developing the model, 4) validating the model by experts, and 5) trying out the model (dissemination). The object of this study was the English for cruise line bartender at the International Bali Institute of Tourism. In collecting the data, three instruments were use namely questionnaires, guided interviews, and document analysis. The study shows that eight topics are requires to be developed. The topics are getting to know you, setting up a bar, kinds of drink, drink recipe, and taking beverage order, we are sorry, cruise vacationers, and job interview. The materials were designed by following the English for Specific Purposes (ESP) material design involving input, content focus, language focus, and task. Since English for Housekeeping is part of ESP that is under English for Occupational Purposes, the steps of the interactive data analysis method consist of data reduction, data display, and conclusion drawing. The results of expert judges' validation were analyzed descriptively by comparing the scores of two raters. The quality of the developed materials was categorized as good material. Thus, it can be used as the source for learning by prospective the secretary of Cruise Line Bartender Program at The International Bali Institute of Tourism.
\end{abstract}

Keywords: English Learning Materials, Cruise line, Bartender 


\section{INTRODUCTION}

Many people around the world choose Bali as their place to have a vocation. Like a magnet of tourism, Bali must prepare their professional human resources based on their skill and knowledge, and people who work in the tourism industry must be able to interact in the International language, especially in English. As a foreign language in Indonesia, English should be used to communicate with international people. They come from different countries use the English language to communicate with others. English becomes an essential means of communication occupations that put English proficiency, both written and spoken, as one of the recruitments. Besides, developed global communication makes student must be able to use English in their conversation. According to Paul Lewis, which indicates that English puts ranked 3rd as the language most used in countries worldwide recorded a total of 172 languages [1]. From the survey results, it is concluded that English is the most widely used language by the countries in the world [2]. Mastering the English language must be that the English language is a medium to introduce Indonesian to ASEAN and all the world countries.

There are many factors behind the unsatisfied result of Indonesian students in learning language, the fact that English in Indonesia ranked below other Asian countries. Besides, one reason, because the educational institutions do not offer what the students need in studying English, such as a suitable textbook for the students. Palmer and Mackay stated that the language program must focus on the students' needs [3]. English learning is taught to students to achieve language skills for industry, especially in the field of tourism. They were providing opportunities for students to use ESP English to prepare their ability to communicate in the future. It means that teaching English and the instruments in show English must be suitable for the students' purposes. The importance of learning English encourage the writer to design material for students of International Bali Institute of Tourism to master their skill in global competition. Additionally, in a worldwide game, the demand for English is getting higher along with establishing MEA and AEC, which means of speaking English is mandatory if Indonesia wants to compete. Especially in tourism, the important could communicate in English to reach a higher level in global competition.

As a professional in tourism, students must be able to speak and communicate using the English language. In making students professional, teachers should be teaching English for tourism, which is known as ESP, is the teaching of English, not as an end in itself but as an essential means to an identifiable goal" [4]. Examples include English for bartender, where students learn the necessary language to carry out the various daily tasks, which comprise their job. In sum, ESP is English for vocational purposes. However, they supposed to do so with no, or very limited, preparation time" From the above point, the researcher concluded that the needs analysis needed to provide development of an appropriate ESP Material for Bartender. It will be known how to design ESP Material for Bartender based on the student's needs, there are many components in the development of ESP Competence for Tourism, and it could create material for cruise line bartender.

On the other hand, the researcher found the instructor used the irrelevancies' between the current syllabuses (textbook) for teaching cruise line bartender at The International Bali Institute of Tourism. The researcher also found the irrelevance of the syllabus and the material with the students' needs at The International Bali Institute of Tourism with the goal of the program students' work in the cruise line bartender department. Some of the reasons explained as follows: The syllabus used at the International Bali Institute of Tourism was designed by the English teacher who didn't base on work as a bartender. So far, no one has done the research and made material for cruise line bartender students based on their needs. It can be seen on the textbook's material for its cruise line bartender students was limited and needed more new terminology in a bartender. Development of materials for students in these conditions for the cruise line bartender program it must and make a renewed material.

Considering the importance of need analysis, both from the experts working on the cruise line bartender, on the other hand, this research focused attention on what material is needed and how to develop what is required by students into teaching material. So the study about it is necessary and must be done immediately, if not done then problems will continue for a very long time. The impact of this problem is that the International Bali Institute of Tourism students cannot compete and will give a bad image to their institution. Based on the rationale, the research entitled " Developing English Material for Cruise Line Bartender for Students of International Bali Institute of Tourism' will write by the study as a form of my future contribution to the development of material at International Bali Institute of Tourism. 


\section{METHOD}

Since this study aimed to develop a book for cruise line bartender class, this research applied an $R$ \& D (Research and Development) design. R \& D are applied to create products that can be used for the teaching-learning process in the field of education. Once products are completed, they must be experimented and revised until they match the quality and effectiveness. This study adopted the design proposed by Dick and Carey [5]. The model consists of several stages; 1 ) problem determination (need analysis), 2) design of the model, 3) developing the model, 4) validation by an expert, and 5) dissemination (trying out the model).

The following stages will explain the stages in this study, and the first stage carried out is the determination of the problem, wherein the first stage was presented problems that are found in the field such as students' problems in the process of learning English, materials that are less appropriate to the needs of students, especially in ESP learning. The second step is designing books according to students' needs, in this step involves making materials and books for the bartender program. The third step in this research is the development of the material contained in textbooks, and the fourth step is evaluating the book material that is tested by experts in the field ESP education, as well as from the Bartender. Finally, to find out the quality of the books that have been developed. The scheme of the stages in the research can be seen below:

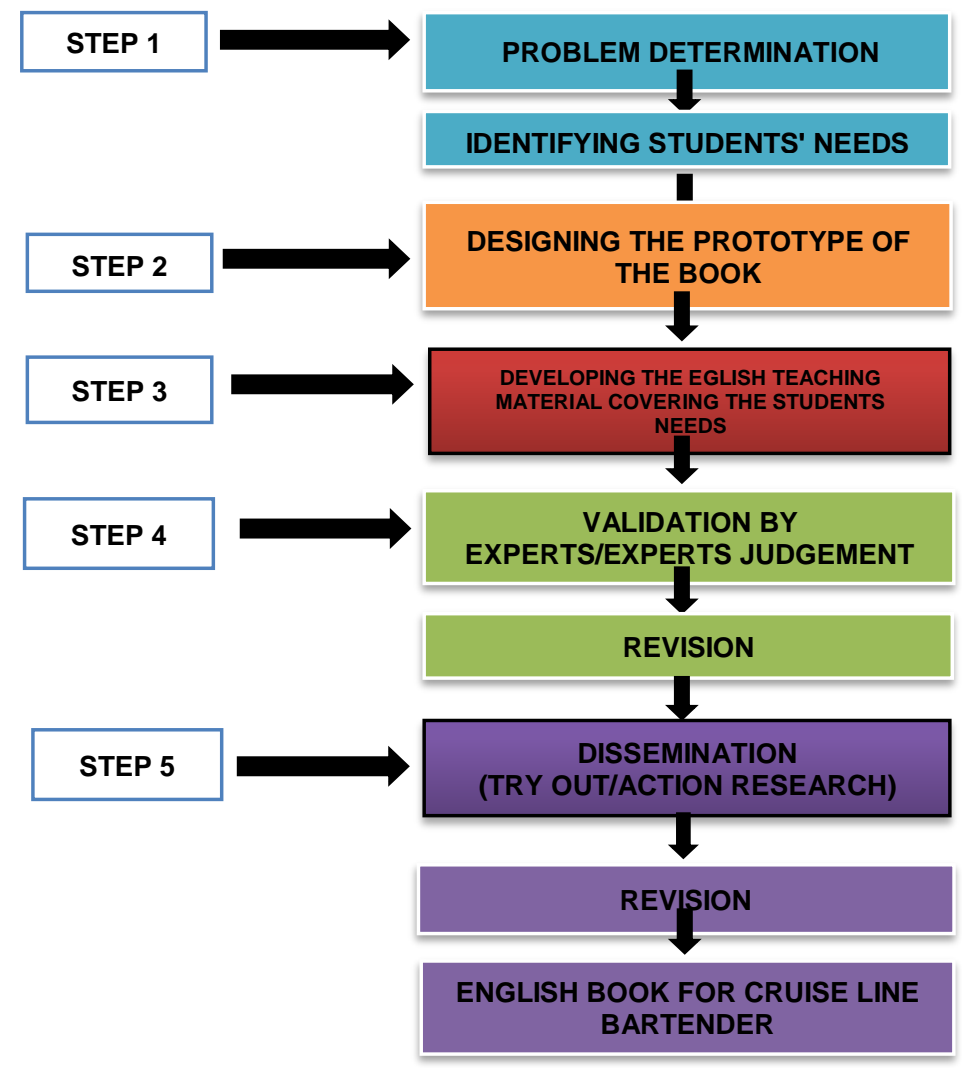

Picture 1. Dick and Carey's (2001) Theoretical Framework

\section{A. Research Procedure}

The following steps will explain the steps in this study, the first stage carried out is the determination of the problem, wherein the first stage was presented problems that are found in the field such as students' problems in the process of learning English, materials that are less appropriate to the needs of students, especially in ESP learning. The second step is designing books according to students' needs, in this step involves making materials and books for the bartender program. The third step is the development of the material contained in textbooks, and the fourth step is evaluating the book material tested by experts in the field of ESP education, and also from the expert in Bartender. Lastly, to find out the quality of the books that have been developed.

\section{B. The Technique of Data Collection}


Based on the research questions and the purpose of the study, data was collected through elaborated some techniques to carry out a need analysis. Furthermore, questionnaire and interview for the alumnus students of International Bali Institute of Tourism and the expert of the bartender who works at cruise line or hotels, and they were distributed. The questionnaire is applied in the need analysis stage. The students' characteristics and learning resources are observing by doing the analysis. Then the questionnaire and interview used for students' needs, interest to know options, or suggestions the materials from the expert material. Moreover, the questionnaire also used to revise the materials.

\section{Method of Data Analysis}

Qualitative and quantitative data analysis was used to analyze the data obtained based on an interactive data analysis method by Miles and Huberman [6] and Gregory's formula (2000). The steps of the interactive data analysis method by consist of data reduction, data display, and conclusion drawing [6]. Meanwhile, the results of expert judges' validation were analyzed quantitatively by comparing the scores of two raters by using Gregory's formula (2000).

According to Miles and Huberman [6], the process of data analysis followed these steps:

\section{a) Data Reduction}

Data reduction refers to the process of selecting, focusing, simplifying, abstracting, and transforming the data that appear in written-up field notes or transcriptions. The data reduction/transforming process continues after fieldwork until a final report is completed. Qualitative data could be reduced and transformed in many ways: through selection, through summary or paraphrase, through being subsumed in a larger pattern, and so on.

\section{b) Data Display}

The second primary flow of analysis activity is data display. Generically, a display is an organized, compressed assembly of information that permitted conclusion drawing and action. Looking at displays helps us to understand what is happening and to do something-either analyzing further or taking action based on that understanding. The qualitative data were presented in tables, matrices, graphs, charts, and so forth so that the researcher can see what is happening and either draw justified conclusions or move on to the next step analysis the display suggested may be useful.

\section{c) Conclusion Drawing and Verification}

The third stream of analysis activity is conclusion drawing and verification. Then, verification could be done after the exact patterns were found. The preliminary conclusion would be temporary and might change if some strong evidence could not support the data. Yet, if the conclusion is supported by evidence that is valid and consistent, then the result would be credible.

\section{Gregory's Formula}

Gregory's formula (2000) was used to test the students' need to analyze questionnaires' content validity. To determine the quality of the developed material, in this step, the product is developed. It covers teaching materials and the product of this research. The product which will be in the form of a document will be validated by experts using expert judgment. The data will be analyzed descriptively using Gregory's formula (2000).

Note:

A: $1^{\text {st }}$ examiner not relevance and $2^{\text {nd }}$ examiner, not relevance

B: $1^{\text {st }}$ examiner relevance and $2^{\text {nd }}$ examiner, not relevance

C: $1^{\text {st }}$ examiner, not relevance and $2^{\text {nd }}$ examiner relevance

D: $1^{\text {st }}$ examiner relevance and $2^{\text {nd }}$ examiner relevance

The coefficient is between 0.00 to 1.00 .

Determining the criteria, formula from Nurkancana and Sunartana [7] was used. It was presented in the table below.

Table 1. Criteria and Category of Content Validity

\begin{tabular}{lll}
\hline Criteria & Interval & Validity Category \\
\hline $\mathrm{M} i+1.5 \mathrm{SD} i \leq \max$ score & $0.8-1.00$ & Very High \\
$\mathrm{M} i+0.5 \mathrm{SD} i \leq \bar{X}<\mathrm{M} i+1.5 \mathrm{SD} i$ & $0.6-0.79$ & High \\
$\mathrm{M} i+0.5 \mathrm{SD} i \leq \bar{X}<\mathrm{M} i+0.5 \mathrm{SD} i$ & $0.4-0.59$ & Average \\
$\mathrm{M} i+0.5 \mathrm{SD} i \leq \bar{X}<\mathrm{M} i-0.5 \mathrm{SD} i$ & $0.2-0.39$ & Low \\
$\mathrm{Min}$ score $<\mathrm{M} i-1.5 \mathrm{SD} i$ & $0.0-0.19$ & Poor \\
\hline
\end{tabular}


Note:

$A=$ number of disagreements between the two judges;

$A$ and $C=$ number of different judgments between the two judges;

$D=$ number of agreements between the two judges.

Based on the formula of the tabulation above, the calculation for Gregory's formula was:

$$
\begin{aligned}
& \text { Content Validity }=\frac{\mathrm{D}}{A+B+C+D} \\
& \text { Content Validity }=\frac{25}{0+0+0+25}
\end{aligned}
$$

Content Validity $=1.00$

$$
\text { Content Validity }=\frac{\mathrm{D}}{(\mathrm{A}+\mathrm{B}+\mathrm{C}+\mathrm{D})}
$$

\section{FINDING AND DISCUSSION}

This section presents the results of the research and relates them to the theories that underlining this study. It is divided into three. Those are affiliated into three research questions of this study:

- The learning material needed to be developed for cruise line bartender students

- The development process of the learning material

- The quality of the developed material

1. The learning material needed in advanced English material for cruise line bartender students of The International Bali Institute of Tourism. Consisted of eight topics. The unit build in the developed book are as follows:

\section{a. Getting to know you}

The first unit was about 'Getting to know you.' To know kinds of expressions or identity exposure, text informal and formal situations, then be able to expressions of Greeting People, and introduce themselves orally.

\section{b. Setting up Bar}

The second unit was about 'Setting up bar" in this unit, students can know kinds of bar equipment than could describe the function of bar equipment.

\section{c. Kinds of drink}

The title of the third unit was 'Kinds of drink.' For the students to be able to identify types of drink, then explain and identify drink with alcohol and no - alcohol

\section{d. Drink Recipe}

The fourth unit in this section was 'Drink Recipe.' From this unit, the students were expected able to write a recipe then explaining the drink recipe orally.

e. $\quad$ Taking Beverage Order

The fifth unit was about 'Taking Beverage Order.' This unit in the learning process students is expected to be able to speak in the language being studied expression there was used in taking the order. Then ready to handling drinks reservations at the bar.

f. We are sorry

The sixth unit was 'We are sorry" 'in this section and can identify the steps of handling complaints. Then able to express how to handle a complaint.

h. Cruise Vacationers

The seventh unit was 'Cruise vacationers.' This section students could know kinds of expressions of asking for the vacancy then the structure of use conditional sentence. 


\section{g. Job Interview}

The eighth unit learned about 'Job Interviews.' To be able to know the things should be prepare before the interview, then able to write application letter \& curriculum vitae.

2. The second finding is the development process of the learning material.

In developing a set of English materials for the cruise line bartender students, the research procedure proposed adopted the design by Dick and Carey [5]. The model consists of several stages; 1) problem determination (need analysis), 2) design of the model, 3) developing the model, 4) validation by an expert and 5) dissemination (trying out the model), The first step of the research is the problem determination, which includes the need analysis of the cruise line bartender students at The International Bali Institute of Tourism. The objectives of these first steps are 1) to identify students' problem in learning English then identify students need to learn English, especially in ESP at cruise line bartender students. The second step is designing the Book for Cruise line Bartender Students. This second step involves creating the materials as well as the book for the cruise line bartender program. The third step of the research is the development of the book. The fourth step is to evaluate the book's material books material by experts, and the last step is to try out the book to see how effective the model is by conducting action research. The fourth and fifth steps are conducted to find out the quality of the book being developed. Moreover, for the dissemination stage of the last steps (trying out the model) can not be done due to the pandemic, it means the proses of know the quality of the book stops at validation by an expert.

Moreover,it includes the looks of the developed book. Each unit consists of input, a content focus, a language focus, a vocabulary focus, a vocabulary task, a listening task, speaking task, a reading task, which may be elaborated as follows:

a. Input

The researcher developed the input by providing pictures and various inquiry as stimulant material for activities, which helped the students generate ideas about the topic. The input in each sub-topic provided pictures taken from Google and the researcher taken by herself. For instance, and the first unit discussed getting to know you. Then, the picture and questions related to how to introduce themselves and others were provided.

b. Content focus

In this section, students will convey some information related to the subject. It will help students to get meaningful communication. The content focus in the material developed is represented as a reading section, and showing the material related to every unit. In unit 1, a reading passage about how to introduce yourself and others was provided. It contained the explanation of the rule about introducing self and others and addressing systems informal situations.

c. Language focus

The developed material also provided the language focus to enable the students to use language. In language focus, the students have chances to take the language to pieces, study how it works, and practice putting it together again. For instance, in unit 1 , the language focus concerned the grammatical usage of using am, are, is, and have/has, which would be used by the students how to introduce themself.

d. Listening Task

In the process of developing audio or listening in each sub-topic, the researcher prepares the audio equipped with the adaptation of several conversations following the target language of the students. From textbooks and YouTube related to English for Cruise Line Bartender. The tape scripts were also provided at the end of the developed material. There were some types of tasks in the listening activity: fill in the gap, short answer questions, and listen to multiple choices.

e. Speaking Task

After the listening task, the students were also provided with speaking tasks. There were several sorts of speaking tasks within the developed material, like role-play scenarios, practice a conversation in pairs. However, the conversation in the correct order, choosing the correct words in italics, practicing the conversation, and completing a conversation with the words in the box. Those speaking tasks were done in group and pair works.

f. Reading Task

After the students reading a reading passage within the content focus, there was also a reading task that has done. It was done in group work, pair work, and individual. There were some sorts of reading tasks within the developed material like true or false, answer some questions, list some vocabulary, and put the sentence into the right order.

g. Writing Task 
In this section is a writing assignment, the material developed and prepared must be diverse; the aim of diverse material and task makes students do not get bored during the learning process, especially in writing task. The activities will give several examples that can be used in providing writing assignments and activities that are offered. They are filling in the gaps, answering questions, writing a few sentences, completing conversations in a few sentences in the box, and writing a cover letter based on the job vacancies provided.

Each topic would meet the courses' objectives according to the needs of cruise line bartender students. The course objectives are the students able tell the expression of welcoming greeting guests, say to the expression of introducing self and others, describe the bar and bartender work filed, tell the expressions of giving information of drink and how to make a drink. Furthermore, tell the language expressions of handling guests reservation table, tell the language expression of beverage order, tell the language expressions of vacationers, tell the expressions of handling guests' complaint, write a cover letter and resume, and answer the questions of job interviews.

The learning materials that were developed also covered the target skills, including listening, speaking, reading, and writing. Because the cruise line bartender students would use English as a communicative language where they would use English to communicate with the English-speaking guests; furthermore, the design of the material followed the ESP materials' design proposed by Hutchinson and Waters [8]. It consists of input, content focus, language focus, and tasks. The input in each unit contained some pictures, dialogues, and some brainstorming questions identified by the cruise line bartender students.

3. The last finding is regarding the quality of the developed book in the study, There were two expert judges and a practitioner who judged the developed material. From the evaluation of developed material; then, it could be revised into learning materials that were preferable to be used to encourage the teaching and learning process. The experts' judgments' point of view showed that developed material was as good material. In establishing the developed material quality, there were some aspects of being examined. Those were layout and design, activities and tasks, skills, language type and content, and subject and content. Concerning the quality of the developed materials for teaching English for cruise line bartender of students at The International Bali Tourism Institute, this subchapter discussed the result of product evaluation from expert judges and product revision. To determine the quality of the material that should be developed, the first inspection process, namely checking the checklist, is left to the experts. Material evaluation on the checklist based on proper ESP material criteria. The evaluation of the materials on the checklist was based on the criteria of suitable ESP materials suggested by Litz [9], Hutchinson and Waters [8], and Tomlinson [10]. The five scales on the checklist used were excellent (5), good (4), average (3), below average (2), poor.

Table 2. The Results of Product Quality from Expert Judgment

\begin{tabular}{cccccc}
\hline $\begin{array}{c}\text { Number } \\
\text { of } \\
\text { Item }\end{array}$ & $\begin{array}{c}\text { First } \\
\text { Expert } \\
\text { Judge }\end{array}$ & $\begin{array}{c}\text { Second } \\
\text { Expert } \\
\text { Judge }\end{array}$ & $\begin{array}{c}\text { Number of } \\
\text { Item }\end{array}$ & $\begin{array}{c}\text { First } \\
\text { Expert } \\
\text { Judge }\end{array}$ & $\begin{array}{c}\text { Second } \\
\text { Expert } \\
\text { Judge }\end{array}$ \\
\hline 1. & 4 & 5 & 15. & 4 & 5 \\
2. & 4 & 5 & 16. & 5 & 4 \\
3. & 4 & 5 & 17. & 5 & 4 \\
4. & 4 & 5 & 18. & 4 & 5 \\
5. & 4 & 5 & 19. & 4 & 5 \\
6. & 5 & 4 & 20. & 4 & 5 \\
7. & 4 & 5 & 21. & 4 & 5 \\
8. & 4 & 5 & 22. & 4 & 5 \\
9. & 5 & 4 & 23. & 4 & 5 \\
10. & 4 & 5 & 24. & 4 & 5 \\
11. & 4 & 5 & 25. & 5 & 4 \\
12. & 5 & 4 & Total & 103 & 117 \\
\hline
\end{tabular}




\begin{tabular}{rrrrr}
\hline 13. & 5 & 4 & Total & 220 \\
14. & 5 & 4 & score & \\
\hline
\end{tabular}

The table above presented the result obtained from the expert judges toward the quality of the product. After gaining the scores which were given by the expert judges, the data on Table 3. Was determined by applying the formula suggested by Nurkancana and Sunartana [7]. The quality was measured using the Ideal Mean $(\mathrm{M} l)$ and Ideal Standard Deviation (SDI). The formula could be seen in Table 3.

Table 3. The Formula Proposed by Nurkancana and Sunartana [7]

\begin{tabular}{ll}
\hline Criteria & Category \\
\hline $\bar{X} \geq \mathrm{M} i+1.5 \mathrm{SD} i$ & Excellent Material \\
$\mathrm{M} i+0.5 \mathrm{SD} i \leq \bar{X}<\mathrm{M} i+1.5 \mathrm{SD} i$ & Good Material \\
$\mathrm{M} i-0.5 \mathrm{SD} i \leq \bar{X}<\mathrm{M} i+0.5 \mathrm{SD} i$ & Average Material \\
$\mathrm{M} i-1.5 \mathrm{SD} i \leq \bar{X}<\mathrm{M} i-0.5 \mathrm{SD} i$ & Below Average Material \\
$\bar{X}<\mathrm{M} i-1.5 \mathrm{SD} i$ & Poor Material \\
\hline
\end{tabular}

The further explanation of the formula can be seen as follows:

$\mathrm{Mi}=\frac{1}{2}$ (ideal maximum score + ideal minimum score $)$

$\mathrm{SD} i=\frac{1}{3} \mathrm{M} i$

$\mathrm{Mi} \quad=$ Ideal Mean

$\mathrm{SD} i \quad=$ Ideal Standard Deviation

$\bar{X} \quad=$ The score of the expert judges

As mentioned previously, there were twenty-five items in the scoring rubric. The maximum and minimum score of each item were 5 and 1 . Thus, the total of the maximum score was 250 and the minimum score is 50 . The next step was calculating the Ideal Mean $(\mathrm{M} I)$ and Ideal Standard Deviation $(S D I)$. The detail calculation of the data investigated the quality of the product could be presented below.

$$
\begin{aligned}
\mathrm{Mi} & =\frac{1}{2}(\text { ideal maximum score }+ \text { ideal minimum score }) \\
\mathrm{Mi} & =\frac{1}{2}(250+50) \\
\mathrm{SD} i & =\frac{1}{3} \mathrm{Mi} \\
\mathrm{SD} i & =\frac{1}{3} \times 150 \\
& =50
\end{aligned}
$$

After the value of $\mathrm{Mi}$ and $\mathrm{SD} i$ were calculated. Then, it was put into the criteria of product quality to obtain the interval score of each category. The calculation was shown in the following.

a. Excellent Material

$\bar{X} \geq \mathrm{Mi}+1.5 \mathrm{SD} i$

$\bar{X} \geq 150+(1.5 \times 50)$

$\bar{X} \geq 225$

The material can be categorized as an excellent material if the total score gained from expert judges was more than 225

b. Good Material

$\mathrm{M} i+0.5 \mathrm{SD} i \leq \bar{X}<\mathrm{M} i+1.5 \mathrm{SD} i$

$150+(0.5 \times 50) \leq \bar{X}<150+(1.5 \times 50)$

$175 \leq \bar{X}<225$

The material can be categorized as good material if the total score gained from expert judges was between $175 \leq \bar{X}<225$

c. Average Material

$\mathrm{Mi}-0.5 \mathrm{SDi} \leq \bar{X}<\mathrm{M} i+0.5 \mathrm{SD} i$

$150-(0.5 \times 50) \leq \bar{X}<150+(0.5 \times 50)$

$125 \leq \bar{X}<175$

The material can be categorized as average material if the total score gained from expert judges was between $125 \leq \bar{X}<175$ 
d. Below Average Material

$\mathrm{Mi}-1.5 \mathrm{SD} i \leq \bar{X}<\mathrm{M} i-0.5 \mathrm{SD} i$

$150-(1.5 \times 50) \leq \bar{X}<150-(0.5 \times 50)$

$75 \leq \bar{X}<125$

The material can be categorized as a below material if the total score gained from expert judges was between $75 \leq \bar{X}<125$

e. Poor Material

$$
\begin{aligned}
& \bar{X}<\mathrm{Mi}-1.5 \mathrm{SD} i \\
& \bar{X}<150-(1.5 \times 50) \\
& \bar{X}<75
\end{aligned}
$$

The material can be categorized as poor material if the total score gained from expert judges was less than 75 .

Table 4. The Interval Score of the Category of Product Quality

\begin{tabular}{lll}
\hline Criteria & Interval Score & Category \\
\hline $\bar{X} \geq \mathrm{M} i+1.5 \mathrm{SD} i$ & $\bar{X} \geq 225$ & Excellent \\
$\mathrm{M} i+0.5 \mathrm{SD} i \leq \bar{X}<\mathrm{M} i+1.5 \mathrm{SD} i$ & $175 \leq \bar{X}<225$ & Good \\
$\mathrm{M} i-0.5 \mathrm{SD} i \leq \bar{X}<\mathrm{M} i+0.5 \mathrm{SD} i$ & $125 \leq \bar{X}<175$ & Average \\
$\mathrm{M} i-1.5 \mathrm{SD} i \leq \bar{X}<\mathrm{M} i-0.5 \mathrm{SD} i$ & $75 \leq \bar{X}<125$ & Below Average \\
$\bar{X}<\mathrm{M} i-1.5 \mathrm{SD} i$ & $\bar{X}<75$ & Poor \\
\hline
\end{tabular}

The table above presented the interval score of the product quality. Since the total score obtained from the experts' judgment was 220, then, it was converted into the interval score of the category of product quality by Nurkancana and Sunartana [7], therefore, the developed material was categorized as good material.

\section{A. PRODUCT REVISION}

There were two experts involved in this study. Both of them are experts in language teaching materials. They were given a checklist for determining the quality of the developed materials to fulfil the criterion.

The material was designed by following the model of ESP material design of Hutchison and Waters (1987), which consist of input, content focus, language focus, and task.

Although the product categorized excellent, some points need to be revised and added to the product. The points that need to be reviewed and added as follows:

\section{a) Adding pictures}

According to experts, a textbook should contain various pictures. Make the students more interested in learning, and pictures should be added in the textbook. The picture should appropriate to the topic. However, authentic pictures can give an illustration of real workplace situations.

\section{b) Input}

The input still contained first pictures with a question as stimulus material activities, new language items, a correct model of language use, and atopic communication. However, the experts suggested that the researcher should add more pictures to the input and added more questions as a stimulus for the students.

\section{c) Content Focus}

Content focus still contained non- linguistic content non - linguistic content in the form of reading passage. The function was to teach the students the theory of the topic. Therefore, the students could generate meaningful communication question that is related to the passage. The function was to check the students' whether they understood or not the reading passage. Then expert suggested that reading passage use the language with a simple topic.

\section{d) Language Focus}

Language focus contains common language expression of English for cruise line bartender, the material which related to bar. The function was to encourage learners' uses language accurately and introduce the learners to common language expressions of English for cruise line bartender. In this part, the expert suggested adding more expression in some units.

\section{e) Task}


In this part, content, and the task of writing, reading, listening and speaking, designed with the students need in learning English. However, the expert suggested to give the students fill in the gaps activity rather than to ask students only write the dialogue, the expert also suggested to add more speaking activity and also this task must suitable use in online learning.

\section{f) Revision the spelling and grammatical mistakes}

Some mistakes in spelling and also grammar was found in the materials development. It seemed that it was not big trouble, but those mistakes can influence the structure of language and instruction the experts suggested to revised the spelling and grammar mistakes to avoid misunderstanding.

\section{CONCLUSION}

The materials that were needed by cruise line bartender students have been found and rearranged into a set of ESP materials in this study. It contained eight main topics. The first unit was about getting to know you. Second, was about setting up a bar. The third unit was about kinds of drinks. The fourth unit was about a drink recipe. The fifth unit was about taking beverage orders. The sixth unit was about we are sorry. The seventh unit was about cruise vacationers. The eighth unit was about job interviews. Each unit consisted of a cover of the unit, an input, a content focus, a language focus, a vocabulary focus, a listening task, a speaking task, a reading task, and a writing task. From the previous explanation, it can be concluded that the learning materials needed by cruise line bartender students is a learning materials that cover their English needs as bartender [11]

In the present study, this study will adopt the design proposed by Dick and Carey [5]. The model consists of several stages; 1) problem determination (need analysis), 2) design of the model, 3) developing the model, 4) validation by the expert and 5) dissemination (trying out the model). The study began by analyzing the needs of cruise line bartender students by using a questionnaire, interview guide, and document analysis. The researcher then designed the material and the achievements, input, content focus, language focus, and tasks from the result of needs analysis. Then, after the material was designed, the experts re-evaluated to make it more effective. Further, the material was developed as a developed material. Also, the developed materials were judged by the expert judges and the practitioner by using a material evaluation checklist based on the criteria of suitable ESP materials suggested by Litz [9], Hutchinson and Waters [8], and Tomlinson [10].

Based on the expert judgment result, the total score of advanced material obtained from the experts' judgment was 220. Then, it was converted into the interval score of the category of product quality by Nurkancana and Sunartana [7], the developed material was categorized as good material. This score gathered because the expert judges considered the content of the developed material was relevant to be used.

\section{REFERENCES}

[1] M. P. Lewis, Ethnologue: Bahasa dunia, Dallas: SIL internasional Edisi keenam belas, 2009.

[2] Anggayana, I. Budasi and I. Kusuma, "Social Dialectology Study of Phonology in Knowing English Student Speaking Ability," The Asian EFL Journal, vol. 25, pp. 225- 244, 2019.

[3] R. Mackay and P. J, Language spesific purpose: Program design and evaluation., Rowley: Newbury House, 1981.

[4] R. Mackay and A. J. Mount ford, The teaching of English for Spesific Purpose: theory and practice. In English Spesific Purpose: A case study approach., London: Longman, 1987.

[5] W. Dick , L. Carey and J. Carey, The Systematic Design of Instruction 5th Ed., New York: Addison Wesley Educational Publisher Inc., 2001.

[6] M. Miles and A. Huberman, Qualitative Data Analysis: A Methods Sourcebook, London: SAGE Publisher, 2014.

[7] W. Nurkancana and P. Sunartana, Evaluasi Hasil Belajar, Surabaya: Usaha Nasional, 2011.

[8] T. Hucitson and W. Alan, English for spesific purpose: A learning- centered approach., Cambridge : Cambridge University Press, 2008.

[9] D. Litz, "Textbook Evaluation and ELT Management: A South Korean Case Study," Asian EFL Journal, vol. 4, pp. 1-53, 2005. 
[10] B. Tomlinson, Material Development in language teaching, Cambridge : Cambridge University Press, 1998.

[11] "Developing English for Housekeeping Material for Students of Sun Lingua College SingarajaBali," The Asian EFL Journal , vol. 23, pp. 164-179, 2019. 